\title{
Changemakers and Change agents: Encouraging Students as researchers through changemakers programs.
}

\begin{abstract}
:
This paper examines the role played by a student-organised research conference in the age of research-led teaching and active learning. Drawing on our experiences of organising a departmental conference in Geography in March 2016 and March 2017, we begin to outline how institutional support and funding for student-led "Changemakers" projects can not only introduce students to specific aspects of research (in the case of our conference, to disseminating and communicating research findings), but also encourage collaboration and mutual support outside of formal staff-student hierarchies of teaching, learning and marking.
\end{abstract}

Keywords: Research-led teaching, active learning, changemakers,

\section{Introduction:}

How do we make students better researchers, more employable and more active members of the university? Universities across the UK have begun to tackle this question by adopting 'Research-led teaching' (hereafter RLT) strategies that explicitly reconfigure the relationship between staff and students, particularly concerning the role of the student as an active learner.

The push towards RLT features as part of a broader re-conceptualisation of the role of the student as stakeholders who do not just pay to be taught, but to benefit from a university's research. For example, University College London has adopted a 'Connected Curriculum' platform, which sets out six dimensions of the research process in which all students, regardless of level should have the opportunity to participate. Swansea University proudly states its commitment to research-led teaching on its homepage, promising that the relationship between 
research, practice, and teaching is developed over time so that it evolves as a fundamental part of the University's planning and Lincoln university is known for its students as producer strategy, whereby all students should learn through research. ${ }^{i}$

More radically, some commentators (Wenstone, 2012, Cook-Sather, Bovill and Felten, 2014, Healey, Flint and Harrington, 2014, Dunne and Zandstra, 2011) have challenged the conception of the student role as one of consumers - paying to benefit from teaching and research. Instead, they argue that students should be empowered to act as partners in their education. This demand for student inclusion is not unfounded: in the UK in 2015, the National Union of Students conducted a survey which showed $80 \%$ of students would like to be more involved in curriculum design (Havergal, 2015; Turner et al., 2017).

While RLT has incorporated opportunities for students to 'practice' doing their own research into many Geography curricula, emphasis has often been placed on the stages of curriculum and research design, data collection, and analysis. In this article, we wish to point to another program that can encourage students to engage in research, develop the skills employers seek and become active members of the university, thus satisfying the demands of the student as consumer while offering the potential for them to reconceptualise themselves as active agents in their education: Changemaker's programs.

Defined broadly, a Changemaker's program is a university funded opportunity for students (and sometimes, staff in partnership with students) to design, refine, implement and evaluate a change they would like to see in their department. They have become popular in many universities in the United Kingdom ${ }^{\mathrm{ii}}$, with similar programs operating in the USA at Northwestern University and a Changemaker's Hub at the University of San Diego, as well as the MacChangers program at McMaster University in Canada ${ }^{\text {iii }}$. 
This paper illustrates the benefits of such a program to geography education through the example of a departmental conference, which was co-organised by four of the authors of this paper (add initials). The conference was motivated by the need for students to gain first-hand experience of research dissemination, but its goals went beyond this in three important and interconnected ways. First, we felt there was a need to create more opportunities for students to share their research findings - whether they originated from a first-year group project, or a final-year dissertation - outside of the formal marking process. While staff in our department have often informally discussed the impressive rigour and innovation produced in undergraduate coursework, the audiences for this work are limited to just a few tutors and assessors, and there are few spaces in which undergraduate students can publicise, and take pride in, the products of their research work, and these tend to favour a select few elite performers. ${ }^{\text {iv }}$

Second, we felt that for both staff and students to fully participate in the activities encouraged by RLT initiatives both groups require more than training: what is needed is an opportunity for both groups to explore the research outputs of one another. In this respect, the conference aimed to generate a different 'atmosphere' in the department - a space outside of formal hierarchical relationships of teaching, marking, and learning, where staff and students could engage with each other's work on peer terms, as could be expected at any academic research conference (on geographers' insights on atmospheres which informed our thinking, see McCormack 2008; Bissell 2010; Barnfield 2016).

Third, and relatedly, our aim was to ensure that the growing expectation to engage with different publics, placed on academic staff in the UK, extended to students - something which, as undergraduate students and postgraduate teaching assistants, we felt there were few opportunities within the limited number of formal contact teaching hours. In the second part of 
this paper, we discuss our experience of organising a departmental conference, and reflect on the extent to which it addressed some of these concerns.

\section{Theoretical framework:}

\section{Changemakers as a means of developing employability}

It is increasingly clear that students do not just attend university for the pleasures of intellectual development, but to gain a wide repertoire of skills including leadership, applying for funding, project design and presentations skills that will help them secure employment and succeed in the workplace, skills that cannot be easily taught in the lecture theatre or seminar (Cranmer, 2006). While academics are divided upon the benefits of such a drive towards employability (Boden \& Nedeva, 2010), there is no doubt that the student experience has changed to one of making oneself employable through careers and skills sessions, volunteering, work experience and internships to supplement the degree, no longer a guarantor of employment (Tomlinson, 2008).

We understand excellent teaching to be that which engages students in course content while providing a chance for students to develop a broader set of soft skills. Contrary to some, we do not believe these two goals are contradictory. Educators need not become automatons producing robots for graduate recruitment schemes as Williams (2016) argued the Government White Paper 'Success as a Knowledge Economy' menaces. Just as importantly, nor must they produce erudite but hopelessly unemployable knowledge seekers for knowledge's sake. There is a balance, and RLT has been lauded as one way to achieve this (Charles, 2017). We believe Changemakers Programs offers educators opportunities to do the same. These programs usually position themselves in opposition to the neo-liberal economic politics that lies behind 
the drive for employability (Dunne and Zandstra, 2011) and yet there is nothing inherently contradictory between the two (Marie, 2018). Changemaker programs can provide the opportunity for students to develop their employability while also ensuring that students are active members of their university, holding themselves as much as the university responsible for their educational experience.

Changemaker's projects come in all shapes and sizes, yet some generic characteristics can be outlined:

- The project must involve some degree of student involvement in the design, delivery and evaluation of the project

- The projects are often funded by the university, with students having to apply and provide expenses and receipts for all purchases. Students provide a budget when submitting an application

- The projects are designed to be implemented throughout the year, with students required to evaluate their project

- Projects are often seed funded, with a view to seeing them become a regular feature of departmental life

- The Changemakers staff can help with administrative and logistical issues (booking rooms, expenses, printing and finance etc) but the majority of the work is undertaken by the project team

Changemakers projects can thus equip students with a set of skills, such as project management, budgeting, evaluation, managing change, persuasion, teamwork and leadership, as well as providing untrammelled ownership of an idea and its execution. Some examples should help. In 2017, UCL geography students ran three 'Shut Up and Write!' sessions for staff 
and students. In these sessions rooms were booked and refreshments were provided for all to come and spend 20 minutes on focused writing before taking a 15 minute break. This cycle would be repeated until participants wished to leave, or the time was up. This style of 'group writing alone' has proved extremely effective for motivating $\mathrm{PhD}$ students. Another Changemaker's project funded by the University of Exeter in 2014 involved creating a module fair for second and third year students making their choices. Again, with funding from the department, refreshments, time and rooms were provided so staff could chat to students about their modules. Both projects were created and designed by students. These projects provided the students who lead them with skills such as event organisation, communication and evaluation, as well as enhancing the learning experience of others.

The detailed example given in this paper of organising a departmental conference exposed us to the difficulties of scheduling and negotiating the various demands of speakers, to finding funding, clean crockery and glasses for tea, coffee and wine receptions. Recent research into the importance of organising conferences at the doctoral level has shown that the 'experiential role of the student in the development of their doctoral training and the social interactions encountered within this process, are just as essential as the more traditionally structured supervisor-student relationship' (Mercer, Kythreotis, Lambert, \& Hughes, 2011, p. 153). However, we found that presenting to audiences, fielding awkwardly phrased and lengthy academic questions and successfully navigating a drinks reception are valuable skills for undergraduate as well as graduate students.

As shown by these cases, Changemaker's programs allow students to actively contribute to a part of departmental life they are usually unaware of and thus develop great awareness of and responsibility for the departmental environment they inhabit. 


\section{Learning through research}

The turn in universities towards RLT has developed alongside a concomitant understanding that students are not simply passive receptacles to be filled with knowledge by a learned staff member, but are instead actively engaged in knowledge production (Freire, 2000; Micheletti, 2010).

With the publication of the Boyer (1990) report in the United States, it was argued that a new model of undergraduate education would have to be underpinned by research. More importantly for this paper, the report argued that the production of knowledge should not be an exclusive activity, but rather one that all members of an institution can participate in' (McLinden, Edwards, Garfield, \& Moron-Garcia, 2015, p. 24). Since then, the uptake of RLT initiatives has been geographically widespread (Toni, Maphosa, \& Wadesango, 2014).

In the United Kingdom, the Research Excellence Framework (REF) has meant that universities have become increasingly dependent upon their research profiles as an indicator of their prestige. Enticing new students with the benefits of a university's research portfolio has become central to marketing strategies for new student intakes. As emphasis has been placed on a university's research portfolio, a concurrent change in staff student relationships has occurred where staff research interests and the research process must benefit the students (Trowler \& Wareham, 2008). For example, pedagogic research into how teaching is undertaken (scholarship of teaching and learning) is one way this can be ensured. Felten (2013) has argued that one of the principles of good scholarship of teaching and learning is to work with students and doing so can help them learn many tacit skills about both research and teaching.

Rather than using the degree to teach students about a discipline more broadly, RLT focuses on the research skills and content that individual staff members must acquire, providing 
students with a thorough grounding on not just the content or theories within a subject, but the process of knowledge creation. We suggest that Changemakers can help develop a range of similar skills. The Changemakers program at University College London is seen to be fully in line with the principles of RLT, with Fung (2017, p. 140)) pointing out that through the program 'students learn through enquiry, connect with staff and have to produce outputs, such as reports, to persuade their audience of the utility of the change. The students are also all encouraged to discuss their work at UCL's annual Teaching and Learning conference.'

\section{Student-led learning}

At the heart of both of RLT and Changemakers is the active, engaged student who does not passively consume knowledge, but is active in creating it. Dunne and Zandstra (2011) have conceptualised this new trend towards student engagement on a quadrant outlining the different leadership and role students may play (figure 1). 


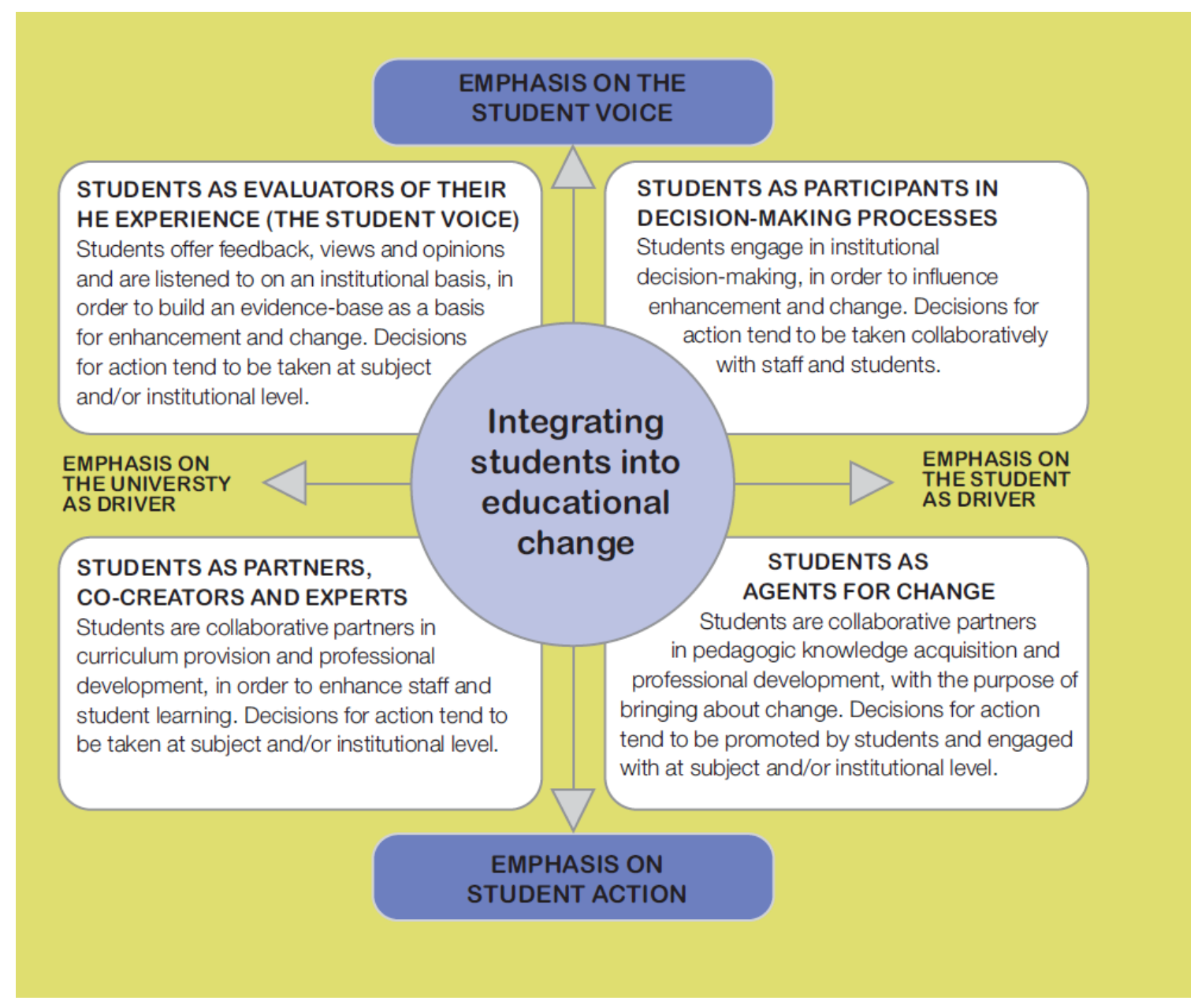

Figure 1: The different types of student change agents (Source: Dunne and Zandstra, 2011,

The breadth of projects that can be undertaken via a Changemakers program is vast, yet all should fall into the bottom half the diagram and many will fall into the right-bottom corner, due to their emphasis on student design and student action. For us, a particular strength of this approach, is that students become the change they want to see, rather than having this fit into a university education strategy.

In comparison, the four different ways Mick Healey (2005) describes RLT being deployed are all staff-led. Healey (ibid) describes how RLT can be 'research led', and content is directly related to the activities of the research staff within a department. At our own institution, firstyear Geography students are assessed by interviewing a staff member and writing a report on 
their research (Dwyer, 2001). This method could be seen as 'RLT-lite' in terms of student participation. Students are simply made aware of staff research work and its link to their own learning and assessment. Rather than view this as a superficial lip-service to the ideals of RLT, this approach is an entirely pragmatic and relatively simple way of establishing the importance of research from the start of a degree program. It also requires less investment in terms of academic labour and time for both staff and students.

Secondly, 'research-orientated' teaching is where the curriculum places emphasis as much on understanding the processes by which knowledge is produced in the field as on learning the codified knowledge that has been achieved; (Healey, 2005: 192). Students are encouraged to understand the actual processes of research, with an emphasis on the production of knowledge through the research process. Thirdly, 'research based' teaching involves radical changes to the traditional student experience, with students learning content and processes through the participation in research-like processes such as scenario or project-based learning. Curriculums may be designed to completely upend approaches to lecturing or assessment. The onus may well be on methods that eschew traditional examination in favour of knowledge production by students. Finally, 'research informed' teaching is that which draws systematically on research and theories of teaching itself. All four styles offer varying degrees for student engagement yet Healey suggests that in practice, all RLT involves overlap between the four.

These approaches and examples place staff at the helm of RLT, whether it be through new curriculum design or actively involving students in the creation of academic articles. What they find more difficult is to create opportunities for students to identify areas to that would strengthen their education and take them forward themselves. For example, while undergraduate students are viewed as active learners with important insights into research design and doing research, their research outputs are rarely recognised beyond 'coursework' - 
that is, a training exercise which is formally assessed and rarely appreciated beyond the staff involved in the teaching and assessment of a particular course. Within the discipline of geography, it is very rare for an undergraduate student to present at an academic conference. Even when they do submit to conferences such as the Australian Conference of Undergraduate Research or British Conference of undergraduate research these are separate to their formal program of study, and they will not be part of the organising team. It is rarer still for them to publish an academic article based on dissertation research. Even when undergraduates do publish in undergraduate journals, Metcalfe (2007: 1) suggests such research has 'a long way to go to achieve the level of credibility required to make an impact on academia'.

In our case, we identified that creating opportunities for students to disseminate their research work would generate new ways for students and staff to engage with each other through that most important part of producing research: peer review. It is in cases like this that Changemakers can offer something traditional approaches to RLT cannot: an opportunity for students to lead on the curriculum design, a set of soft skills involved with creating, designing and implementing a project and a suspension of the student-staff relations where all become equal.

We recognise the criticism that can be levelled at Changemaker programs that they are not fully inclusive, instead favouring students who tend to volunteer (Moore-Cherry, Healey, Nicolson and Andrews, 2016). However, the outputs of such a project can be inclusive in the same way that RLT is. Both the outputs of a project and RLT can force students to act as partners within a space that is defined by others. Arguably it is better for students to have a role in defining this space, as we did for the conference, because they have a better understanding of the student experience and thus what would most benefit other students (Cook-Sather et al, 2014). Changemaker programs additionally benefit those that choose to participate, by enabling them to bring about changes that are important and meaningful to them. 


\section{Skills development and peer collaboration across hierarchies}

Genuine student engagement in Changemakers necessarily implies disrupting some of the existing hierarchical structures and power inequalities which are deeply embedded in teaching and learning processes, by simple virtue of empowering students to find a fault and address it themselves directly. Furthermore, the learning that comes about from a Changemakers project is experiential (Kolb, 2014; Moon, 2004). Reynolds (2009, p. 389) suggests that experiential learning lead to a 'less hierarchical interpretation of authority in that learning is derived from dialogue with peers'. This position was central to the values and aims which informed the departmental conference discussed in this paper. There are a range of challenges in all of this, from staff and student vulnerability, students acting out a consumerist role, time and a lack of incentivization for participation on both sides (Marie \& McGowan, forthcoming). Nevertheless, there are a host of benefits from students and staff being perceived as peers.

When staff and students view each other as peers, widely held myths about what academics do and what academic life is like can be debunked. In a fascinating paper from 1979 Ramsden examined student 'atmospheres' of learning across different academic departments in British universities. He concluded that student perceptions of the academic environment can be just as important as metrics such as topic and the attitudes of staff (Ramsden, 1979).

While there is plenty of research that has problematised student evaluations of teaching (SET) (Alhija \& Fresko, 2009; Spooren, Brockx, \& Mortelmans, 2013; Su \& Wood, 2012), they can reveal the perceptions Ramsden spoke about in 1979. In research-intensive universities, too many students feel the staff are distant figures who are only available during lectures and office hours, and that departments lack a sense of community (Kandiko \& Mawer, 2013). On top of 
this, research is something staff do, not students (Brew, 2006). In New Zealand, interviews with 34 students from a variety of disciplines reveals that 'some students have an early sense of proximity to and/or participation in a research community, while for others, research remains, through their undergraduate years, a remote phenomenon' (Robertson \& Blackler, 2006, p. 215). In the UK, research has shown that students may believe they benefit and lose out simultaneously from research intensive staff, particularly due to their unavailability (Healey, Jordan, Pell, \& Short, 2010). A limited number of contact hours in teaching was a concern voiced by many staff and students in our department. Yet that same study revealed that students recognised that their awareness of the nature of research and the development of research skills increased most when they were actively involved in undertaking research projects.

For us, Changemakers programs can help alter student perceptions of research if a student is allowed to help create a space for research to be discussed. Just as RLT seeks to bring students into the research process, bringing them into the fold of research dissemination can help them understand why research takes up so much time and its importance to their department, while providing another chance to engage with staff.

Importantly, we sought for this space to work across some of the divides in the geography department. The conference would be an opportunity to engage with peers across the undergraduate, graduate, postgraduate and staff levels; and beyond the silos of physical and human geography research - and thus the name 'Conversations in Geography: Bridging Gaps' was chosen for the event.

\section{Conversation in Geography in March 2016}


The idea for a student-led departmental conference came out of a discussion in November 2015 between two of the authors (put in the initials of those authors). As doctoral students and postgraduate teaching assistants, we were uniquely placed to have insights on the various pressures and demands experienced by staff and students in terms of combining research and teaching/learning. The training provided by our institution on active learning and research-led teaching provided us with core knowledge and awareness of many of the issues discussed above. The announcement that funding and support was available through UCL ChangeMakers to work on Connected Curriculum-related initiatives was timely. Once the funding for the conference was awarded, an email was sent out to all undergraduate students to recruit two further organisers who would have equal say in putting together the conference. An excerpt from this initial communication to undergraduate students is presented in Figure 2. Notable among applicants was a desire to 'get more involved with the department'. This has proved to be a particularly important desire that students have identified as important for their study. One first-year and one second-year undergraduate student joined the team. The present paper is coauthored by all four conference organisers (initials).

We are Steve and Daisy PhD students in the Geography Department, and we have been awarded some funding from UCL Changemakers (https://www.ucl.ac.uk/changemakers/projects) to organise a one-day departmental conference in Term 2. We are keen to make this a conference for all UCL geographers, bringing together research ideas and findings from across undergraduate, 
postgraduate and staff projects. We are hoping to get broad support from the Department for this initiative, and already have the backing of several members of academic staff (cc'ed here).

The conference theme, programme for the day, dates, and presenters, are all yet to be decided, and we are looking for 2 or 3 undergraduate students who would be interested in organising the event with us. In addition, we thought The Bloomsbury Geographer might want to be the official media partner of the event. The student organisers will be rewarded with $£ 150$ each by UCL Changemakers. However, there is a fair amount of work involved, both in the run-up and on the day, as we will be circulating a call for participants, selecting contributions and organising them into sessions, sorting out room bookings, catering, etc. It is therefore important that you feel confident this additional work won't interfere with your studies. At the same time, this should prove to be a valuable and rewarding experience, giving many insights into event organising and the dissemination of academic research.

If any of you are interested, please email us with a few sentences about who you are, why you want to get involved, and why you would be a very useful person to have on board. Please do so by Friday, 27 November. The organising team will be expected to attend the UCL Changemakers introductory lunch and training session on 1 December, 13.0016.00 .

Figure 2: Recruiting conference co-organisers 
Through the successful application to Changemakers, we were awarded $£ 750$ to run a one-day conference. A Wednesday was chosen as a suitable day to organise the event, as a weekday when teaching commitments are less in the afternoon due to sporting activities. An email was also sent to staff members, and several academics committed to supporting the group organising the conference, particularly in promoting it among undergraduate students. We were aware that there would be a particular barrier in recruiting undergraduate presenters for many of the reasons discussed above: students face mounting pressures on their time, in order to meet the requirements of their courses and also acquire transferrable skills, and often generate an income to fund their studies, through various commitments outside of the University; they may not perceive benefits from participating in such an event, because they have limited, if any, prior experience of research conferences; finally, they were likely to see their own research as somehow 'inferior,' and to feel intimidated by it being scrutinised at such an event, by an audience including their lecturers and tutors. Following initial feedback from staff and students, we provided encouragement and detailed guidance wherever possible, in order to address some of these concerns (see Figure 3). The Call for Papers stressed that we were interested in all aspects of research from across the departmental hierarchy: we would consider first-year projects and fieldtrip findings as seriously as research grant applications from senior staff. We also attached a document outlining how to write an abstract for those geographers who may never have written one. 


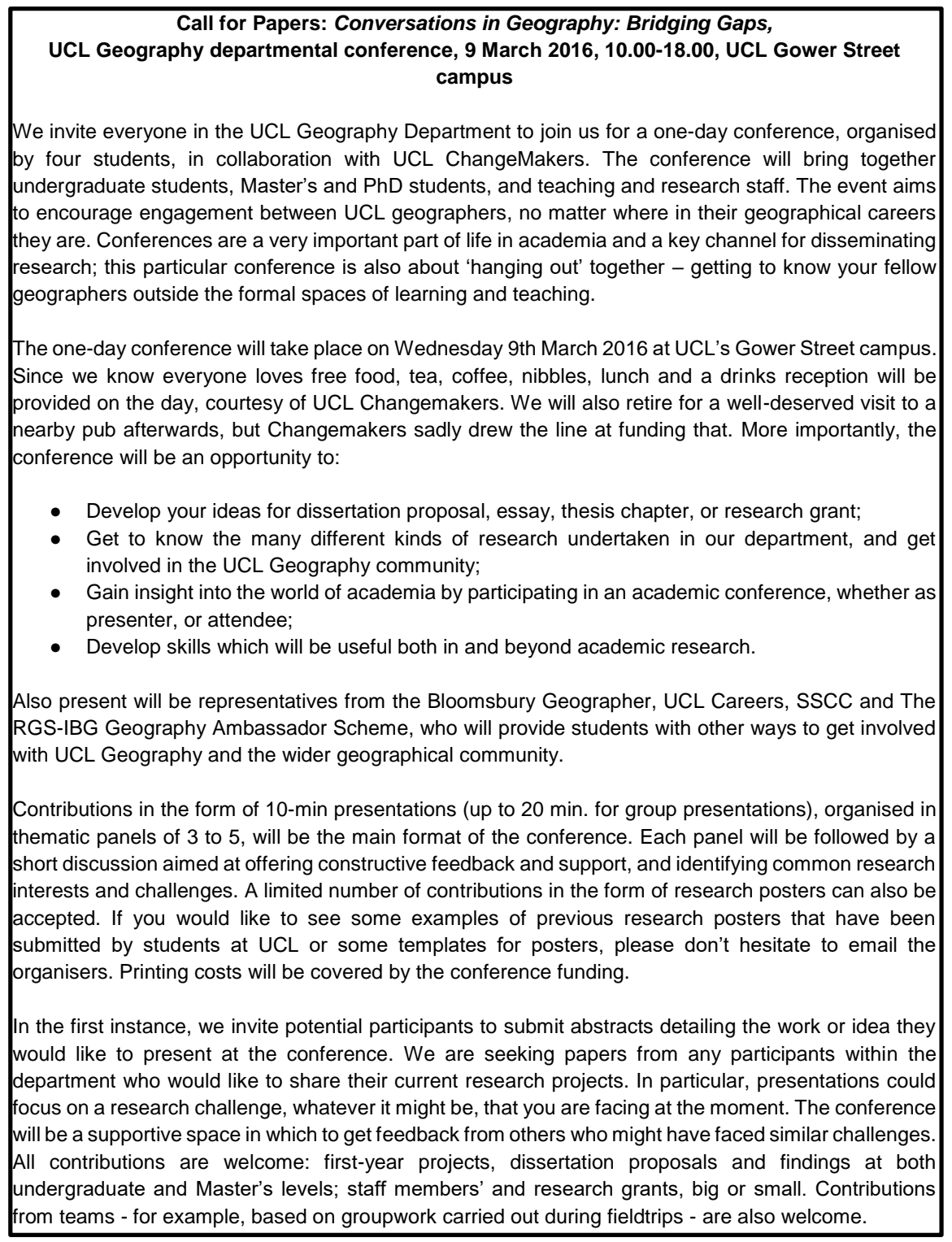

Figure 3: Call for Papers

After 3 months of frantic logistical and administrative work, we held the conference on 9 March

2016. Through making presentations shorter and the conference day longer (9.30 to 18.30), we

were able to include every speaker who submitted a paper, as was our goal. This included 17

papers presented by 20 staff and students, comprised of 8 presentations by staff members, 3 by

PhD students, 2 by MSc students and 4 by undergraduate students (see table 1 for details). 
Table 1: Details of participants and sessions

\begin{tabular}{|c|c|c|}
\hline $\begin{array}{l}09: 45- \\
10: 15\end{array}$ & Registration and coffee & \\
\hline \multirow{4}{*}{$\begin{array}{l}10: 15- \\
11: 15\end{array}$} & \multirow{4}{*}{\begin{tabular}{|l} 
Panel session 1: \\
Geographies of Production \\
and Consumption
\end{tabular}} & $\begin{array}{l}\text { 1. Lecturer Geography, Collaboration and Big Data Part 1: } \\
\text { Undergraduate and Masters }\end{array}$ \\
\hline & & $\begin{array}{l}\text { 2. Lecturers - Geography, Collaboration and Big Data } \\
\text { Part 2: PhD and other research }\end{array}$ \\
\hline & & $\begin{array}{l}\text { 3. Student ( }{ }^{\mathrm{Tu}} \text { Year) Who cooperates and who not: } \\
\text { Retailer response to municipality plastic bag ban in } \\
\text { Nepal }\end{array}$ \\
\hline & & $\begin{array}{l}\text { 4. Masters student - New Geographies of 'Making': The } \\
\text { Resurgence of manufacturing of advanced formats in the } \\
\text { post-industrial urban context - The case of } 3 D \text { printing } \\
\text { industry in London }\end{array}$ \\
\hline $\begin{array}{l}11: 15- \\
11: 30\end{array}$ & Coffee break & \\
\hline \multirow{3}{*}{$\begin{array}{l}11: 30- \\
12: 45\end{array}$} & \multirow{3}{*}{$\begin{array}{l}\text { Panel session 2: Places, } \\
\text { connections, infrastructures }\end{array}$} & $\begin{array}{l}\text { 1. Lecturer - Improving the resilience of major ports } \\
\text { and national supply chains to extreme coastal flooding } \\
\text { due to tidal surges } \\
\text { 2. Masters Student - Alter-globalization: } \\
\text { transnational connection and contradiction }\end{array}$ \\
\hline & & $\begin{array}{l}\text { Undergraduate ( } L^{m} \text { year) - Bloalversity and conservation } \\
\text { eefforts in Singapore }\end{array}$ \\
\hline & & $\begin{array}{l}\text { 4. PhD student - Small Changes with Big Consequences? } \\
\text { Exploring the Use of Urban Infrastructure by Commuter } \\
\text { Cyclists } \\
\text { 5. Lecturer - Inhabiting infrastructure: exploring the } \\
\text { interactional spaces of urban cycling }\end{array}$ \\
\hline 12:45- & $\begin{array}{l}\text { Pick up lunch and head to } \\
\text { keynote }\end{array}$ & \\
\hline \multirow{2}{*}{$\begin{array}{l}13: 15- \\
14: 00 \\
14: 00- \\
14: 10\end{array}$} & Keynote & Lecturers x 2 \\
\hline & Short break & \\
\hline \multirow{4}{*}{$\begin{array}{l}14: 10- \\
15: 25\end{array}$} & \multirow{4}{*}{$\begin{array}{c}\text { Panel session 3: Shifting } \\
\text { perspectives in geographica } \\
\text { research }\end{array}$} & $\begin{array}{l}\text { Lecturer - Ask the fellows who cut the hay: } \\
\text { Valuing the ideas of people in nature conservation }\end{array}$ \\
\hline & & $\begin{array}{l}\text { 2. Masters student - The construction of ebola as securtty } \\
\text { threat } \\
\left.\text { 3. Student ( } 3^{\text {10 }} \text { year }\right) \text { - Biopolitics, } \beta \text {-Thalassemia and the } \\
\text { Chwreh }\end{array}$ \\
\hline & & $\begin{array}{l}\text { Student (2nd Year) and Lecturer - Bridging the gap } \\
\text { between academic and undergraduate research: how to } \\
\text { make a dissertation out of a lump of coral }\end{array}$ \\
\hline & & $\begin{array}{l}\text { 5.Lecturer - Later life leisure travel and the circulation of } \\
\text { expectation }\end{array}$ \\
\hline $\begin{array}{l}15: 25- \\
15: 45\end{array}$ & Coffee break & \\
\hline \multirow[b]{2}{*}{$15: 45-$} & & $\begin{array}{l}\left.\text { 1. Lecturer and students ( } 2{ }^{\text {Itu }} \text { year }\right) \text { - Palaeotoxicity: } \\
\text { Reconstructing the effects ofpollutants on freshwater } \\
\text { organisms }\end{array}$ \\
\hline & & $\begin{array}{l}\text { 2. PhD Student - Carbon Sequestration and Biodiversity } \\
\text { Following Active Tropical Forest Restoration: } 18 \text { years of } \\
\text { Change in Kibale National Park, Uganda }\end{array}$ \\
\hline
\end{tabular}




\begin{tabular}{|c|c|c|}
\hline |16:45 & $\begin{array}{l}\text { Panel session 4: } \\
\text { Understanding change }\end{array}$ & $\begin{array}{l}\text { 3.Student (3. year) - Weaponising vulnerability: } \\
\text { Madrid's post-crisis squatters as a force for change in } \\
\text { the neoliberal city } \\
\text { 4.PhD Student - We are outside of the Ark: climate } \\
\text { change, Pacific islands and the allegorical impacts } \\
\text { of Noah }\end{array}$ \\
\hline $\begin{array}{l}16: 45- \\
18: 30\end{array}$ & \multicolumn{2}{|c|}{$\begin{array}{l}\text { Interactive session with 'stations'tor RGS Ambassadors, Bloomsbury } \\
\text { Geographer, Careers }(T B C), S S C \text {. Wine and nibbles served. }\end{array}$} \\
\hline
\end{tabular}

Of the staff presentations, two were presented with either a single student or a group of students. The $£ 750$ was used to provide lunch, along with $£ 10$ book vouchers for speakers, which was intended as a small gesture of appreciation for the contributors to this 'experimental' conference. The remaining funds were used for a coffee and evening reception that included various groups affiliated with UCL Geography such as the Bloomsbury Geographer, Geographical Society, The UCL Conservation Group and the Royal Geographical Society Geography Ambassadors from UCL. These organisations have activities in which geographers can get more broadly involved (volunteering for the RGS-IBG, attending conservation talks and walks and socialising/ organising talks for the Geography Society). Apart from the 20 presenters, we estimate that approximately 30 students and staff attended all or part of the conference day.

\section{Discussion:}

The conference was evaluated by a debrief of the organisers, alongside a report to UCL ChangeMakers and a follow up interview for the University website. ${ }^{\mathrm{V}}$ We use these resources, to guide our reflections and discussions, for implementing RLT via Changemakers programs that are student-led.

Testimonials from staff and students throughout the day suggested that the conference fostered a sense of community. With regular breaks for coffee, lunch and a drinks reception, 
geographers of all stripes had multiple chances to talk to one another. Exposure to the wider activities of geographers through the conservation society, RGS ambassadors and Geographical Society was designed to show students the different ways their academic studies could be supplemented by other geographical activities. While it is difficult to assess whether this has led to an uptake in these activities, this was not our direct aim: fostering a sense of community, and generating new kinds of atmospheres in the Department, which might eventually go on to generate more specific new collaborations and engagements, was an outcome which, according to attendee comments, was delivered.

A key aim of the conference was to break down barriers between staff and students through the shared practice of research dissemination. Table one shows the conference schedule was organised in such a way that panels would contain a mixture of staff, undergraduates and graduate students. We instructed the moderators to try and encourage debate and dialogue between staff and students, particularly if students were either shy or lacking in confidence on the validity of their research. We also encouraged staff to offer students constructive feedback on their research ideas/proposals/ findings, as this is a practice that is common at academic conferences.

Despite our sustained efforts, attracting undergraduate students to present their research proved challenging. However, some brilliant precedents occurred - one of the conference panels featured a first-year undergraduate presenter alongside the Head of Department. In order to provide further opportunities for undergraduate students to get actively involved, and to engage with the academic staff in new and surprising ways, undergraduate students were recruited to chair sessions. Their feedback suggested that this opportunity to keep lecturers to time, initiate 
and moderate questions and answers, was a valuable experience outside of formal studentteacher relations.

Another goal of the conference was to introduce students from across the human and physical divides to each other's work, identifying areas of mutual concern and future collaboration. This follows a long pedigree of work from scholars toiling at the interface of human/physical geography (Harrison et al., 2004; Massey, 1999, Barry 2016). We deliberately organised our conference program to mix human and physical geographers on shared panels and encouraged questions which challenged presenters to identify crossovers in either their topics, policy relevance or approaches to problems. These broad and inclusive themes enabled us to cluster what were a diverse group of presenters into loosely linked panels: each of the four panels included both human and physical geography research. Inevitably, this presented challenges, but served well our goal of 'bridging gaps'. Both staff and students spoke about being surprised at both the range of work undertaken but also the potential for collaboration.

We received a lot of positive feedback in relation to skills development - both in terms of organising, chairing and presenting research, but also in terms of informally engaging in conversation with others in the Department. A mixture of soft and hard skills were gained by those who took part. A host of undergraduate students learned how to submit an abstract, present a paper and take questions from an audience of academics. For us as organisers, we learned the strategies and approaches required to successfully apply for funding, navigate UCL's labyrinth of room booking software and negotiate catering and refreshments.

Frustratingly, we did not manage to create a conference feedback form from which we can lift direct quotes. However, we managed to get departmental funding for a repeat of the conference and written support from the head of department. Off the back of this, we organised a follow 
up conference in March 2017 which had a higher turnout of 60 people with participation from college students and teachers. The teachers noted that their A-level students very much enjoyed being part of an academic environment.

One avenue that we were unable to explore, yet remains particularly tantalising, would be to encourage conference participants to submit publications to one of the UCL journals, much like this piece, which arose from our presentation at the JGHE annual conference. While we lacked the funding, time and organisation to do so at our previous conference, such goals are very much achievable and entirely in the spirit of Changemaker's programs.

\section{Conclusion}

The success of the 2016 conference and its follow up in 2017 suggest that both staff and students benefitted from a forum where they could treat one another as peers outside of the formal strictures of marked assessment. In planning the conference, we explicitly sought to create an atmosphere of informal, non-marked, non-remunerated, egalitarian support, and thus to make a small yet explicitly political intervention in the learning process. This temporary space was intended to create, albeit briefly, an occasion to interact in new ways, outside of the structures and formal positions which bind staff and students in the everyday spaces of the department. As discussed above, students and staff reported that it fostered a sense of community and while student satisfaction as measured by the UK's National Student Survey (NSS) is influenced by a whole range of factors, it is notable that overall satisfaction in the NSS rose in the UCL Geography department by $14 \%$ between 2015 and 2016 . While we explicitly sought to create a peer environment through our Changemakers project, the projects themselves are also designed to do this, by encouraging students to work with staff to enhance their learning environment. 
As a group of student organisers, we felt that we learned much about research dissemination and the projects of our colleagues. The skills we developed as organisers are invaluable for all our future career plans, regardless of whether our aspirations are within or external to academia. The soft skills our conference provided are so useful because they work across academia and graduate employment. In taking forward a Changemakers project, it is up to the student to decide which skills they want to develop, circumventing a false dichotomy between a focus on employability or research skills.

We thoroughly believe that student-led projects funded through initiatives such as Changemakers or other university funds can complement RLT by putting students in the driving seat of research, instead of having it taught to them. We hope that our own reflections on the process of organising a student-led conference, as well as on its subtle ways of interfering with the everyday structures of academic life, will inspire others to pursue similar, or entirely different, initiatives. 


\section{References}

Alhija, F. N.-A., \& Fresko, B. (2009). Student evaluation of instruction: what can be learned from students' written comments? Studies in Educational Evaluation, 35, 37-44.

Andrews, J., \& Higson, H. (2008). Graduate employability, 'soft skills' versus 'hard'business knowledge: A European study. Higher Education in Europe, 33, 411-422.

Bancino, R., \& Zevalkink, C. (2007). Soft Skills: The New Curriculum for Hard-Core Technical Professionals. Techniques: Connecting Education and Careers (J1), 82, $20-22$.

Barnfield, Andrew. 2016. 'Affect and Public Health - Choreographing Atmospheres of Movement and Participation'. Emotion, Space and Society 20 (August): 1-9.

Barry, A. (2016) 'Manifesto for a Chemical Geography', Inaugural Lecture presented at UCL, $24^{\text {th }}$ January 2017

BBC, (2015) Universities criticised over poor quality teaching. (2015, September 9). BBC News. Retrieved $4^{\text {th }}$ August 2017 from http://www.bbc.co.uk/news/education34197403

Bissell, David. 2010. 'Passenger Mobilities: Affective Atmospheres and the Sociality of Public Transport'. Environment and Planning D 28: 270-89.

Boden, R., \& Nedeva, M. (2010). Employing discourse: universities and graduate 'employability.' Journal of Education Policy, 25, 37-54.

Bovill, C. (2009). Student Engagement: Students as active partners in shaping their learning experience. Retrieved $4^{\text {th }}$ August from Higher Education Academy, University of Glasgow from http://www. sparqs. ac. uk.

Boyer, E. L. (1990). Scholarship reconsidered: Priorities of the professoriate. ERIC.

Brew, Angela. 2006. Research and Teaching: Beyond the Divide. (Basingstoke: Palgrave). 
Cadez, S., Dimovski, V., \& Zaman Groff, M. (2017). Research, teaching and performance evaluation in academia: the salience of quality. Studies in Higher Education, 42, $1455-1473$.

Charles, M. (2017). Teaching, in Spite of Excellence: Recovering a Practice of Teaching-Led Research. Studies in Philosophy and Education, 1-15.

Cook-Sather, Alison, Catherine Bovill, and Peter Felten. Engaging students as partners in learning and teaching: A guide for faculty. John Wiley \& Sons, 2014.

Cranmer, S. (2006). Enhancing graduate employability: best intentions and mixed outcomes. Studies in Higher Education, 31, 169-184.

Dwyer, C. (2001). Linking Research and Teaching: A staff-student interview project. Journal of Geography in Higher Education, 25, 357-366.

Felten, P. (2013) Principles of Good Practice in SoTL. Teaching \& Learning Inquiry, Volume 1, Issue 1, pp. 121-125.

Freire, P. (2000). Pedagogy of the oppressed. Bloomsbury Publishing.

Fung, D. (2017) A Connected Curriculum for Higher Education. London: UCL Press.

Griffiths *, R. (2004). Knowledge production and the research-teaching nexus: the case of the built environment disciplines. Studies in Higher Education, 29, 709-726.

Harrison, S., Massey, D., Richards, K., Magilligan, F. J., Thrift, N., \& Bender, B. (2004). Thinking across the divide: perspectives on the conversations between physical and human geography. Area, 36, 435-442.

Hattie, J., \& Marsh, H. W. (1996). The relationship between research and teaching: A metaanalysis. Review of Educational Research, 66, 507-542.

Havergal, C. (2017) 'Should students be partners in curriculum design?. Retrieved February 10, 2017, from https://www.timeshighereducation.com/features/should-students-bepartners-in-curriculum-design 
Healey, M. (2005). Linking Research and Teaching to Benefit Student Learning. Journal of Geography in Higher Education, 29, 183-201.

Healey, M., A. Flint, and K. Harrington. "Developing students as partners in learning and teaching in higher education." (2014).

Healey, M., Jordan, F., Pell, B., \& Short, C. (2010). The research-teaching nexus: a case study of students' awareness, experiences and perceptions of research. Innovations in Education and Teaching International, 47, 235-246.

Kandiko, C. B., \& Mawer, M. (2013). Student expectations and perceptions of higher education. London: King's Learning Institute.

Kolb, D. A. (2014). Experiential learning: Experience as the source of learning and development. FT press.

Marie, J. 2018. The relationship between research-based education and student/staff partnerships. In: Tong, V., Standen, A. and M. Sotiriou. Shaping Higher Education with Students: Ways to Connect Research with Teaching. (London: UCL Press).

Marie, J and McGowan, S. Forthcoming. Moving towards sustainable outcomes in student partnerships: Partnership values in the pilot year. International Journal for Students as Partners.

Massey, D. (1999). Space-Time, 'Science' and the Relationship between Physical Geography and Human Geography. Transactions of the Institute of British Geographers, 24, $261-276$.

McLinden, M., Edwards, C., Garfield, J., \& Moron-Garcia, S. (2015). Strengthening the Links Between Research and Teaching: Cultivating Student Expectations of Research-informed Teaching Approaches. Education, 2.

Mercer, T., Kythreotis, A., Lambert, C., \& Hughes, G. (2011). Student-led research training within the PhD:"PhD experience" conferences. International Journal for Researcher Development, 2, 152-166.

Metcalfe, D. (2007). The launch of an undergraduate research journal. Reinvention: A Journal of Undergraduate Research. 
Micheletti, G. (2010). Re-Envisioning Paulo Freire's "Banking Concept of Education." Inquiries Journal, 2. Retrieved $4^{\text {th }}$ August from https://www.inquiriesjournal.com/articles/171/re-envisioning-paulo-freires-bankingconcept-of-education

Moon, J. A. (2004). A handbook of reflective and experiential learning: Theory and practice. Psychology Press.

Niamh Moore-Cherry, Ruth Healey, Dawn T. Nicholson \& Will Andrews (2016) Inclusive partnership: enhancing student engagement in geography, Journal of Geography in Higher Education, 40:1, 84-103, DOI: 10.1080/03098265.2015.1066316

Parker, J. (2008). Comparing research and teaching in university promotion criteria. Higher Education Quarterly, 62, 237-251.

Ramsden, P. (1979). Student learning and perceptions of the academic environment. Higher Education, 8, 411-427.

Reynolds, M. (2009). Wild frontiers—reflections on experiential learning. Management Learning, 40, 387-392.

Robertson, J., \& Blackler, G. (2006). Students’ experiences of learning in a research environment. Higher Education Research \& Development, 25, 215-229.

Spooren, P., Brockx, B., \& Mortelmans, D. (2013). On the Validity of Student Evaluation of Teaching: The State of the Art. Review of Educational Research, 83, 598-642.

Su, F., \& Wood, M. (2012). What makes a good university lecturer? Students' perceptions of teaching excellence. Journal of Applied Research in Higher Education, 4, 142-155.

Taylor, J. (2007). The teaching: research nexus: a model for institutional management. Higher Education, 54, 867-884.

Tomlinson, M. (2008). 'The degree is not enough': students' perceptions of the role of higher education credentials for graduate work and employability. British Journal of Sociology of Education, 29, 49-61. 
Toni, N., Maphosa, C., \& Wadesango, N. (2014). Promoting the Interplay between Teaching and Research in the University and the Role of the Academic Developer. Mediterranean Journal of Social Sciences, 5, 19.

Trowler, P. (2011). Researching your own institution: Higher education. Retrieved June, 27, 2013.

Trowler, P., \& Wareham, T. (2008). Tribes, territories, research and teaching enhancing the teaching-research nexus.

Turner, R., Spowart, L., Winter, J., Muneer, R., Harvey, C., \& Kneale, P. (2017). 'The lecturer should know what they are talking about': Student Union Officers perceptions of teaching-related CPD and implications for their practice. Innovations in Education and Teaching International, 54, 143-151.

Wenstone, R. "A manifesto for partnership." London: NUS (2012).

\section{Endnotes}

\footnotetext{
i See more at http://www.swansea.ac.uk/research/activity/teaching/ and http://edeu.lincoln.ac.uk/student-asproducer/

ii For example, Exeter University's Students as Change Agents, Winchester University's Student Fellows, Birmingham City's Student Academic Partners, Lincoln's SEED funding and Reading's PLANT scheme; as well as UCL's ChangeMakers scheme.

iii More on the San Diego program can be found at https://www.sandiego.edu/changemaker/about/ More on MacChangers is available at https://mi.mcmaster.ca/macchangers/

iv Examples include the dissertation prizes awarded by the Royal Geographical Society's Research Groups, and individual prizes for academic performance such as the University of Exeter's 'William Ravenhill Prize'.

${ }^{v}$ That interview can be viewed here https://www.ucl.ac.uk/you-shape-ucl/shape-newspublication/Geography-students-stage-first-student-staff-academic-conference
} 